\title{
GAMBARAN DIMENSI INTERNAL DALAM KONSEP DIRI ANAK ASUH UPTD KAMPUNG ANAK NEGERI SURABAYA
}

\author{
Greisca Rosa Shafira, Oedojo Soedirham \\ Departemen Promosi Kesehatan dan Ilmu Perilaku, Fakultas Kesehatan Masyarakat \\ Universitas Airlangga Surabaya \\ Email: greiscarosa.shafira@gmail.com
}

\begin{abstract}
Every child has rights for survival, growth, development and protection from violence and discrimination. Family's problem such as poverty, bad relationship between children and parents, divorce, and acts of violence in children that affecting children become street children and abandoned children. Street children are very close to violence, neglected by parents, economic problems that result in children not attending school or an inadequate life. Although children in UPTD Kampung Anak Negeri has background as street children and abandoned children but with training that provided, the children are able to achieve a proud achievement. The research was conducted at UPTD Kampung Anak Negeri Surabaya with descriptive method of qualitative approach. The first variable in this research is the characteristics of children consisting of the background of parenting, achievements, and activities that are occupied. The second variable is the internal dimension factor of self-concept consisting of selfidentity, self-behavior, and self-assessment. Instrument in this research is guidance of interview and observation with informant amounted to 8 people who already have achievements. Most children already know their self-identity. Most children are satisfied with their self if it compared with before they in UPTD Kampung Anak Negeri. Most children are already aware and responsible with the task they do. The conclusions of this study indicate that the self-concept supports the creation of good mental health.
\end{abstract}

Keywords: self-concept, mental-health, street-children

\begin{abstract}
ABSTRAK
Setiap anak berhak atas kelangsungan hidup, tumbuh dan berkembang serta berhak atas perlindungan dari kekerasan dan diskriminasi. Masalah keluarga seperti kemiskinan, hubungan anak dengan orang tua yang buruk, dan perceraian, memicu adanya tindak kekerasan pada anak sehingga dapat menyebabkan anak menjadi anak terlantar dan anak jalanan. Anak jalanan sangat dekat dengan kekerasan, mulai dari kekerasan dalam rumah tangga, terabaikan oleh orang tua, dan masalah ekonomi yang mengakibatkan anak tidak sekolah atau kehidupan yang tidak layak. Meskipun Anak asuh di UPTD Kampung Anak Negeri berlatar belakang sebagai anak jalanan dan anak terlantar namun dengan pelatihan yang diberikan, anak-anak tersebut mampu mencapai prestasi yang membanggakan. Penelitian dilakukan di UPTD Kampung Anak Negeri Kota Surabaya dengan metode deskriptif kualitatif. Variabel pertama dalam penelitian ini adalah karakteristik anak yang terdiri dari latar belakang pengasuhan, prestasi, dan kegiatan yang sedang ditekuni. Variabel kedua adalah faktor dimensi internal konsep diri yang terdiri dari diri identitas, diri perilaku, dan diri penilaian. Instrumen dalam penelitian ini adalah panduan wawancara dengan informan berjumlah 8 orang yang telah memiliki prestasi. Sebagian besar anak asuh telah mengetahui identtitas yang tepat untuk dirinya. Sebagian besar anak asuh sudah merasa puas dengan dirinya jika dibandingkan sebelum dia berada di UPTD Kampung Anak Negeri. Sebagian besar anak asuh sudah menyadari serta dapat bertanggung jawab dengan tugasnya. Kesimpulan penelitian ini menunjukkan bahwa konsep diri mendukung terciptanya kesehatan mental yang baik.
\end{abstract}

Kata kunci: konsep diri, kesehatan mental, anak jalanan 


\section{PENDAHULUAN}

World Health Organization (WHO) (dalam Dhar, 2013) secara luas mengartikan bahwa kesehatan tidak hanya meliputi aspek medis, namun juga meliputi aspek sosial dan mental, serta suatu kondisi yang terbebas dari penyakit, cacat dan kelemahan. Kesehatan merupakan suatu kondisi sejahtera baik dari segi fisik, sosial dan jiwa yang memungkinkan setiap orang untuk dapat hidup produktif baik secara sosial hingga ekonomi. Definisi ini sesuai dengan yang tercantum dalam Undang-Undang Kesehatan Nomor 36 Tahun 2009. Hidup produktif dapat dicapai dengan terbebas dari gangguan mental, fisik dan sosial.

Kesehatan merupakan suatu hasil interaksi dari berbagai faktor, baik faktor eksternal maupun faktor internal. Faktor eksternal yang memengaruhi kesehatan terdiri dari faktor budaya, sosial, lingkungan, ekonomi, politik, pendidikan dan sebagainya. Faktor internal yang memengaruhi kesehatan antara lain faktor psikis dan fisik.

Banyaknya faktor yang memengaruhi kesehatan membuat permasalahan kesehatan tidak dapat diselesaikan dengan hanya melihat dari sisi kesehatan internal saja, namun juga harus dilihat dari seluruh dimensi yang memengaruhi kesehatan. Berbagai tindakan dan perbuatan yang dilakukan oleh manusia adalah buah dari dorongan pikiran dan sikap mental yang dimilikinya, sehingga kualitas kesehatan mental menjadi kunci bagi seseorang untuk dapat berfungsi secara sosial di dalam masyarakat (Santoso, 2016).

Individu dapat dikatakan sehat mental ketika individu tersebut dapat menerima, menghadapi, dan sanggup memecahkan permasalahan yang sedang dihadapinya tanpa menimbulkan kecemasan atau kegelisahan, dapat merasakan kebahagiaan dan kemampuan dirinya secara positif. Secara lebih luas kesehatan mental dapat diartikan sebagai kemampuan untuk menyesuaikan diri dengan diri sendiri, dengan orang lain dan dengan masyarakat serta lingkungan dimana seseorang hidup (Santoso, 2016). Freud (2002) mengungkapkan bahwa proses mental merupakan hal terpenting dari diri individu. Proses mental individu dapat dipahami dengan menggunakan konsep diri sebagai unit psikologis yang paling dasar. William H. Fitts (1971) mengungkapkan bahwa konsep diri merupakan aspek penting dalam diri seseorang. Konsep diri merupakan kerangka acuan seseorang dalam berinteraksi dengan lingkungan di sekitarnya. Fitts juga mengatakan bahwa konsep diri memiliki pengaruh besar terhadap tingkah laku individu.

Konsep diri dapat diartikan sebagai gambaran individu tentang dirinya sendiri, meliputi pengetahuan tentang dirinya, pengharapan akan dirinya, dan penilaian terhadap dirinya (Sutataminingsih, 2009). Individu yang memiliki pandangan negatif mengenai kemampuan yang dimilikinya akan membuat individu tersebut merasa bahwa dirinya tidak mampu mencapai tujuannya. Sehingga membuat motivasi dalam dirinya kurang. Individu yang memandang kemampuan yang dimiliki dalam dirinya secara positif akan merasa mampu dan yakin bahwa dia mampu. Hal tersebut memungkinkan individu tersebut termotivasi hingga dapat mencapai aktualisasi diri.

Setiap individu dapat membentuk gambaran diri mereka sejak kecil. Cara individu diperlakukan oleh orang-orang yang berperan penting dalam kehidupannya seperti orang tua, saudara maupun teman sebaya dapat menjadi dasar konsep diri yang terbentuk dalam diri seseorang. (Redjeki, 2013)

Anak jalanan sangat dekat dengan kekerasan, mulai dari kekerasan dalam rumah tangga, terabaikan oleh orang tua, masalah ekonomi yang mengakibatkan anak tidak sekolah atau kehidupan yang tidak layak (Dinas Kesehatan Kota Surabaya, 2012). Jalanan bukanlah lingkungan yang baik untuk tumbuh dan berkembang. Jalanan lebih banyak memberikan hal negatif dibandingkan hal positif. Risiko 
yang dihadapi oleh anak jalanan adalah penyiksaan fisik, kecelakaan lalu lintas, korban kejahatan, penggunaan obat-obatan, konflik dengan anak-anak jalanan lainnya, dan terlibat dalam pelanggaran hukum baik sengaja ataupun tidak (Agustian dan Prasadja, 2000). Penelitian dari M. L. Imasiku dan S. Banda (2010), menjelaskan bahwa anak jalanan rentan mengalami masalah kesehatan mental seperti tingkat stres yang tinggi, masalah emosional, masalah perilaku, hiperaktif, masalah dalam hubungan pertemanan, dan masalah sosial.

Masalah kesejahteraan anak terutama anak jalanan dan anak terlantar terus menjadi perhatian pemerintah di Indonesia. Jumlah anak terlantar di Jawa Timur pada tahun 2012 mencapai 248.667 anak dari 7.926.081 anak.

Jumlah anak jalanan dan anak terlantar di Surabaya juga terus meningkat setiap tahunnya. Data Badan Pusat Statistik Jawa Timur 2012 mencapai 248.665 jiwa. Data dari Dinas Sosial Surabaya (dalam Rahayu, 2016) menunjukkan adanya peningkatan jumlah anak jalanan dari tahun 2011 hingga tahun 2012, yang kemudian mengalami penurunan hingga tahun 2015. Sedangkan untuk jumlah anak terlantar terus mengalami peningkatan dari tahun 2011 hingga tahun 2015.

Banyaknya jumlah anak jalanan maupun anak terlantar menunjukkan ketidakmampuan orang tua dalam memenuhi kebutuhan anak baik secara sosial maupun ekonomi.

Sesuai dengan Undang-undang Nomor 35 Tahun 2014 tentang perlindungan anak, pemerintah dan pemerintah daerah wajib dan bertanggung jawab dalam menyelenggarakan pemeliharaan, perawatan, dan rehabilitasi sosial anak terlantar baik di lembaga pemerintahan maupun di lembaga masyarakat. Adanya peraturan tersebut diharapkan dapat memenuhi dan mengembangkan potensi yang dimiliki anak, agar anak memiliki potensi atau bekal yang dapat diaktualisasikan saat dewasa nanti.
Tabel 1. Jumlah Anak dan Anak Terlantar (usia 5-17 tahun) di Jawa Timur tahun 2012.

\begin{tabular}{llc}
\hline \multicolumn{1}{c}{ Uraian } & Jenis Kelamin & $\mathbf{2 0 1 2}$ \\
\hline Jumlah Anak & Laki-laki & 4.047 .231 \\
& Perempuan & 3.878 .850 \\
& $\begin{array}{l}\text { Laki-laki dan } \\
\text { perempuan }\end{array}$ & 7.926 .081 \\
Jumlah Anak & Laki-laki & 128.050 \\
Terlantar & Perempuan & 120.615 \\
& $\begin{array}{l}\text { Laki-laki dan } \\
\text { perempuan }\end{array}$ & 248.665 \\
\hline
\end{tabular}

Sumber: $\quad$ BPS Jatim, 2012

Tabel 2. Jumlah Anak Jalanan dan Anak Terlantar di Kota Surabaya Tahun 2011-2015.

\begin{tabular}{ccc}
\hline Jenis PMKS & $\begin{array}{c}\text { Anak } \\
\text { Jalanan }\end{array}$ & $\begin{array}{c}\text { Anak } \\
\text { Terlantar }\end{array}$ \\
\hline Tahun & & \\
2011 & 45 & 265 \\
2012 & 114 & 286 \\
2013 & 94 & 363 \\
2014 & 76 & 430 \\
2015 & 76 & 456 \\
\hline
\end{tabular}

Sumber: Dinas Sosial Surabaya (dalam Rahayu, 2016).

Pemerintah Kota Surabaya melalui Dinas Sosial membentuk Unit Pelaksana Teknis Dinas Pondok Sosial Anak Wonorejo pada 4 Januari 2009 dilanjutkan dengan turunnya peraturan walikota Nomor 16 tahun 2012 tentang Unit Pelaksana Teknis Dinas Kampung Anak Negeri. Unit Pelaksana Teknis Dinas (UPTD) Kampung Anak Negeri Kota Surabaya memiliki tugas pokok untuk melaksanakan pelayanan kesejahteraan sosial bagi anak-anak bermasalah secara sosial di Kota Surabaya. Program pembinaan, pengembangan, dan pelayanan anak penyandang masalah kesejahteraan sosial diselenggarakan di UPTD Kampung Anak Negeri. 
Anak jalanan dan anak terlantar yang mendapat pengasuhan di UPTD Kampung Anak Negeri diberikan pelatihan yang dapat digunakan sebagai bekal dalam bekerja. Anak jalanan dan anak terlantar juga mampu mencapai prestasi dari pelatihan yang didapat serta dorongan anak itu sendiri.

Latar belakang dan pengalaman berbeda yang dialami anak asuh UPTD Kampung Anak Negeri dapat memengaruhi kondisi mental masing-masing anak asuh. Kondisi mental ini dapat memengaruhi konsep diri sebagai unit psikologis yang paling dasar pada setiap individu.

Fitts (1971) mengatakan dengan mengetahui konsep diri seseorang, akan mempermudah untuk memprediksi dan memahami tingkah laku orang tersebut. Fitts membagi konsep diri ke dalam dua dimensi yaitu dimensi eksternal dan dimensi internal. Dimensi eksternal merupakan penilaian yang dilakukan mengenai bagaimana individu menilai dirinya melalui hubungan dan aktivitas sosialnya, nilai yang dianut, dan hal lain yang berasal dari luar diri individu. Penilaian dan interaksi individu dengan orang lain memengaruhi dimensi eksternal. Dimensi internal adalah penilaian yang dilakukan individu terhadap dirinya sendiri berdasarkan dunia dalam dirinya sendiri atau batinnya terhadap identitas dirinya, penerimaan/penilaian dirinya, dan perilaku dirinya.

Konsep diri internal akan mengungkap bagaimana individu menggambarkan dirinya dan membangun identitasnya, persepsi mengenai tingkah laku yang berisikan kesadaran mengenai apa yang ia lakukan, dan penilaian yang menentukan kepuasan individu terhadap dirinya atau sejauh mana individu dapat menerima dirinya. Penelitian ini bertujuan untuk (1) mengidentifikasi karakteristik anak asuh UPTD Kampung Anak Negeri Kota Surabaya (2) mengidentifikasi konsep diri anak asuh UPTD Kampung Anak Negeri Kota Surabaya ditinjau dari dimensi internalnya.

\section{METODE PENELITIAN}

Penelitian ini merupakan penelitian kualitatif dengan metode deskriptif. Populasi dalam penelitian ini adalah anak asuh UPTD Kampung Anak Negeri Kota Surabaya. Jumlah anggota populasi sebanyak 35 anak asuh yang berjenis kelamin laki-laki. Populasi memiliki rentang usia 9-19 tahun.

Subjek penelitian yang diambil sebanyak 8 anak asuh yang memiliki kriteria inklusi telah mencapai prestasi di luar UPTD Kampung Anak Negeri dan bersedia menjadi informan dalam penelitian. Sumber data dalam penelitian ini berupa data primer dan data sekunder. Data primer diperoleh dari hasil wawancara mendalam pada subjek penelitian, sedangkan data sekunder di dapat dari dokumen UPTD Kampung Anak Negeri Kota Surabaya.

Penelitian dilaksanakan di Unit Pelaksana Teknis Dinas Kampung Anak Negeri Kota Surabaya yang terletak di Jalan Wonorejo nomor 130, Kelurahan Wonorejo, Kecamatan Rungkut. Pengambilan data dilakukan sekitar bulan Mei 2017 hingga Juni 2017.

Instrument pengumpulan data yang digunakan dalam penelitian ini adalah pedoman wawancara. Variabel yang diteliti adalah faktor-faktor konsep diri internal meliputi identitas diri, diri perilaku, dan diri penilaian.

Teknik analisis data yang dilakukan dalam menganalisis data penelitian kualitatif meliputi 1) reduksi data yaitu dengan memilih hal-hal pokok serta berfokus pada hal-hal penting dalam penelitian, serta dapat menyesuaikan pola dan tema penelitian (Sugiyono dalam Gunawan, 2013), 2) paparan atau penyajian data dengan menyusun informasi yang telah direduksi dan bisa memulai adanya penarikan kesimpulan (Miles \& Huberman dalam Gunawan, 2013), dan 3) penarikan kesimpulan yaitu memunculkan hasil penelitian yang menjawab fokus penelitian sesuai dengan hasil analisis data (Gunawan, 2013). 


\section{HASIL}

UPTD Kampung Anak Negeri Kota Surabaya merupakan salah satu Lembaga Kesejahteraan Sosial Anak (LKSA). LKSA ini berada di bawah naungan Dinas Sosial Kota Surabaya dan beralamatkan di Jalan Wonorejo nomor 130 Kelurahan Wonorejo, Kecamatan Rungkut, Kota Surabaya. Pendirian UPTD Kampung Anak Negeri Kota Surabaya dilatarbelakangi oleh keberadaan anak-anak dengan masalah sosial, antara lain anak terlantar, anak nakal dan anak jalanan. UPTD Kampung Anak Negeri memiliki visi terwujudnya anakanak yang bermasalah sosial berperilaku normatif dan mandiri sehingga dapat melaksanakan fungsi sosialnya secara memadai dalam kehidupan bermasyarakat. Visi tersebut diwujudkan melalui misi 1) menyelenggarakan pelayanan kesehatan sosial bagi anak-anak yang bermasalah sosial dalam sistem panti, 2) menumbuhkan kesadaran untuk mengembangkan potensi yang dimiliki anak-anak yang bermasalah sosial, 3) memfasilitasi tumbuh kembangnya motivasi dan usaha masyarakat dalam penanganan anak yang bermasalah sosial.

Program pelayanan kesejahteraan sosial yang dijalani di UPTD Kampung Anak Negeri Kota Surabaya diantaranya: 1) pemenuhan kebutuhan pangan, meliputi pemberian makan yang memenuhi kecukupan gizi, 2) pemenuhan kebutuhan sandang, meliputi pemberian perlengkapan mandi, cuci, dan pakaian yang layak, 3) pemenuhan kebutuhan papan, meliputi penyediaan fasilitas menginap/tidur di asrama yang representatif, 4) pemenuhan kebutuhan bimbingan mental spiritual, melalui ibadah khusus harian, 5) pemenuhan bimbingan mental perilaku, 6) pemenuhan kebutuhan bimbingan minat keterampilan, 7) pemenuhan kebutuhan minat dan intelektual. Jumlah anak asuh di UPTD Kampung Anak Negeri sebanyak 35 anak asuh yang bermasalah secara sosial, antara lain anak nakal, anak terlantar dan anak jalanan.
Tabel 3. Latar Belakang Pengasuhan Subjek Penelitian.

\begin{tabular}{ll}
\hline \multicolumn{1}{c}{$\begin{array}{c}\text { Inisial Subjek } \\
\text { Penelitian }\end{array}$} & \multicolumn{1}{c}{$\begin{array}{c}\text { Latar Belakang } \\
\text { Pengasuhan }\end{array}$} \\
\hline LAP & Anak terlantar \\
AS & Anak jalanan \\
IZ & Anak terlantar \\
HPP & Anak jalanan \\
AA & Anak jalanan \\
MKP & Anak terlantar \\
JTP & Anak jalanan \\
BS & Anak terlantar \\
\hline
\end{tabular}

Sumber: Data Anak Asuh UPTD Kampung Anak Negeri Kota Surabaya (Dokumentasi).

Prosedur pelayanan yang diterapkan di UPTD Kampung Anak Negeri Kota Surabaya berbasis panti. Prosedur tersebut terdiri dari lima tahap meliputi assessment, orientasi, intervensi, dan evaluasi. Tahap assessment merupakan tahap penelaahan dan pengungkapan masalah untuk mengetahui seluruh permasalahan klien, menetapkan rencana dan pelaksanaan intervensi. Tahap selanjutnya yaitu orientasi. Kegiatan orientasi dilakukan dalam bentuk pengenalan program panti dan lingkungan panti selama satu hari.

Tahap intervensi merupakan bentuk pelayanan yang diberikan kepada klien selama mereka berada dalam panti guna memenuhi kebutuhan fisiologis klien. Tahap intervensi juga merupakan tahap pembentukan dan perubahan perilaku terkait mental, sosial, dan fisik klien, agar memiliki sikap dan perilaku adaptif dan normatif. Tahap selanjutnya adalah tahap terminasi. Tahap ini merupakan pengakhiran/ pemutusan program pembinaan bagi klien setelah mengikuti kegiatan. Tahap terakhir yaitu tahap evaluasi.

Jumlah anak asuh di UPTD Kampung Anak Negeri sebanyak 33 anak. Subjek dalam penelitian ini berjumlah 8 anak yang memiliki rentang usia 15 tahun sampai 19 
tahun. Pada Tabel 3. yang diperoleh dari data dokumen dari UPTD Kampung Anak Negeri Kota Surabaya menunjukkan 4 dari 8 subjek penelitian memiliki latar belakang pengasuhan sebagai anak jalanan, sedangkan sisanya memiliki latar belakang pengasuhan sebagai anak terlantar.

Kompetensi anak asuh UPTD Kampung Anak Negeri Kota Surabaya merupakan kemampuan anak asuh yang ditampilkan sehingga mendapat penghargaan atau pengakuan tertentu. Berdasarkan data dokumen dari UPTD Kampung Anak Negeri di tabel 5, terdapat 7 dari 8 subjek memiliki prestasi dalam bidang olahraga (balap sepeda dan bela diri) dan satu subjek dalam bidang karya tulis novel.
Faktor identitas diri dari dimensi internal konsep diri mengacu pada "sebagai apa diri saya?". Subjek penelitian menggambarkan dirinya serta membangun identitas dirinya. Sebagian besar diri identitas anak asuh ini terbentuk dari kegiatan yang anak asuh lakukan setiap harinya, meskipun terdapat beberapa anak asuh yang belum yakin dengan identitasnya.

HPP menganggap diri identitasnya adalah pemusik. Kesehariannya HPP berlatih musik dan mengikuti pelatihan wirausaha di UPTD Kampung Anak Negeri. HPP belajar bermain gitar melalui guru musik yang mengajar di UPTD Kampung Anak Negeri. Setelah lancar bermain gitar, HPP belajar bermain bass, keyboard dan drum

Tabel 4. Prestasi dan aktivitas yang ditekuni anak asuh.

\begin{tabular}{|c|c|c|}
\hline Inisial & Prestasi & Aktivitas yang sedang ditekuni \\
\hline LAP & Juara 1 Piala KONI Balap Sepeda 2014. & $\begin{array}{l}\text { Latihan rutin dan mengikuti lomba } \\
\text { balap sepeda. }\end{array}$ \\
\hline AS & $\begin{array}{l}\text { 1. Juara } 1 \text { Pertandingan Tinju Amatir di } \\
\text { Tulungagung } 2014 . \\
\text { 2. Juara } 2 \text { Pertandingan Tinju Amatir Piala } \\
\text { Walikota di Rungkut } 2016 \text {. }\end{array}$ & $\begin{array}{l}\text { Lulus dari Surabaya Hotel School, } \\
\text { dilanjutkan dengan bekerja di } \\
\text { penginapan dan centra kuliner. }\end{array}$ \\
\hline $\mathrm{IZ}$ & Juara 2 piala KONI Balap sepeda 2013. & $\begin{array}{l}\text { Lulus dari Surabaya Hotel School } \\
\text { dilanjutkan dengan magang di Hotel } \\
\text { Bintang } 4 \text { Surabaya. }\end{array}$ \\
\hline HPP & $\begin{array}{l}\text { 1. Juara } 2 \text { piala KONI Balap Sepeda } 2012 . \\
\text { 2. Juara } 2 \text { piala KONI balap sepeda } 2013 . \\
\text { 3. Juara } 1 \text { piala KONI balap sepeda } 2013 . \\
\text { 4. Juara } 2 \text { balap sepeda LCC } 2015 .\end{array}$ & $\begin{array}{l}\text { Latihan band/music, mengajar musik, } \\
\text { dan menekuni wirausaha kunir asem } \\
\text { di UPTD Kampung Anak Negeri. }\end{array}$ \\
\hline AA & $\begin{array}{l}\text { Juara } 1 \text { Pertandingan Tapak Suci Di SMA } \\
\text { Muhammadiyah. }\end{array}$ & $\begin{array}{l}\text { Latihan band (drum) dan menekuni } \\
\text { wirausaha cuci motor dan kunir asem. }\end{array}$ \\
\hline MKP & $\begin{array}{l}\text { 1. Juara } 3 \text { Piala KONI Balap Sepeda } \\
\text { Surabaya } 2014 . \\
\text { 2. Juara } 4 \text { New Armada Open Road Race } \\
\text { Magelang } 2015 . \\
\text { 3. Juara } 2 \text { Balap Sepeda Sidoarjo-Trawas. }\end{array}$ & $\begin{array}{l}\text { Latihan rutin dan mengikuti lomba } \\
\text { balap sepeda. }\end{array}$ \\
\hline JTP & Penerbitan Novel karya JTP 2016. & Editing video dan creative creator. \\
\hline $\mathrm{BS}$ & $\begin{array}{l}\text { 1. Juara } 1 \text { Pertandingan Wushu Piala } \\
\text { Walikota Surabaya } 2015 . \\
\text { 2. Juara } 1 \text { Pertandingan Tinju Amatir Piala } \\
\text { Walikota Surabaya } 2016 .\end{array}$ & $\begin{array}{l}\text { Sekolah di SMK Negeri } 10 \text { Surabaya } \\
\text { dan aktif di berbagai macam } \\
\text { ekstrakurikuler (PMI, Konselor, } \\
\text { Jujitsu, Paskibraka). }\end{array}$ \\
\hline
\end{tabular}


secara autodidak. HPP membantu anak asuh lain dalam belajar memainkan alat musik. HPP juga mengajar musik di luar UPTD Kampung Anak Negeri secara privat.

LAP menganggap identitas dirinya sebagai atlet balap sepeda. LAP melakukan latihan secara rutin setiap hari untuk mencapai target yang ingin dia capai. Berbeda dengan LAP, meskipun MKP juga melakukan balap sepeda secara rutin namun MKP tidak merasa identitasnya sebagai atlet sepeda. MKP merasa atlet balap sepeda bukan profesi yang tepat untuk dirinya.

"Sekarang masih belum ada niat belajar yang lain (mencoba hal baru), masih fokus latihan sepeda, soalnya tahun depan persaingan semakin ketat" (LAP)

AS dan IZ menganggap diri identitasnya adalah pelajar. AS dan IZ sama-sama pernah menempuh pendidikan di Surabaya Hotel School. Setelah lulus, AS bekerja di penginapan di Surabaya sedangkan IZ pada saat penelitian sedang dalam masa magang di salah satu Hotel bintang tiga di Surabaya. Meskipun sudah bekerja, AS dan IZ menganggap pekerjaan yang mereka lakukan sebagai pembelajaran dan mencari pengalaman untuk mencapai tujuan. IZ memiliki target untuk dapat bekerja di hotel bintang lima. IZ juga berharap dapat melanjutkan kuliah di bidang perhotelan. AS ingin bekerja di perhotelan kapal layar, namun menurut AS untuk menuju ke sana dia harus lebih banyak belajar dan mencari pengalaman kerja.

Sama seperti AS dan IZ, subjek BS juga menganggap diri identitasnya sebagai pelajar. BS mengikuti berbagai ekstrakurikuler di sekolahnya karena dia suka mempelajari hal baru. Selain untuk memperoleh banyak pengalaman, BS juga ingin memiliki temanteman baru di luar UPTD Kampung Anak Negeri.

"Peran ya sebagai pelajar mbak, soalnya di hotel masih banyak belajar sama masih pengen kuliah juga aku mbak" (IZ)
JTP belum yakin dengan diri identitasnya. JTP pernah menghasilkan karya lukis dan karya tulis berupa novel, namun JTP tidak merasa identitasnya sebagai pelukis ataupun penulis. JTP kini lebih berfokus mempelajari editing video. JTP menekuni belajar editing video karena dia menyukai teknologi dan berharap dapat menjadi youtubers. Kedepannya JTP ingin membuat film yang ia tulis sendiri ceritanya.

Sama seperti JTP, AA juga belum yakin dengan diri identitasnya. AA pernah menghasilkan karya seni lukis yang terjual senilai Rp 12.000.000,- dan dapat membuat handicraft. AA juga bermain alat musik drum dan mengikuti pelatihan wirausaha. Harapan AA setelah keluar dari UPTD Kampung Anak Negeri dia bisa membangun usaha sesuai dengan pelatihan yang ia ikuti saat ini. Berdasarkan hasil penelitian faktor diri identitas, 5 dari 8 subjek sudah mengetahui identitas dirinya dan merasa identitas tersebut tepat untuk dirinya.

Faktor diri perilaku dalam dimensi internal konsep diri merupakan persepsi subjek terhadap tingkah lakunya dan berisi kesadaran mengenai apa yang dirinya lakukan. Faktor diri perilaku ini berkaitan dengan diri identitas. Konsep diri yang baik menunjukkan adanya keserasian antara diri identitas dengan diri perilaku.

HPP memutuskan berhenti berlatih balap sepeda meskipun sudah meraih banyak prestasi. Setelah berhenti dari balap sepeda, HPP memutuskan untuk menekuni pelatihan musik/band yang sudah satu tahun ia ikuti. Setelah mahir bermain gitar HPP mulai belajar alat musik lainnya seperti keyboard, bass, dan drum secara autodidak. Kemampuan HPP dalam bermain musik semakin meningkat. HPP mulai membantu melatih anak asuh lainnya dalam bermain musik. HPP juga pernah menjadi guru les gitar di luar UPTD Kampung Anak Negeri.

LAP dan MKP melakukan latihan balap sepeda secara rutin setiap hari. Selain latihan balap sepeda mereka juga mengikuti kegiatan lain seperti pelatihan wirausaha, 
namun mereka lebih berfokus dengan latihan balap sepedanya. LAP merasa bahwa latihan sepeda memang kebutuhannya sebagai atlet dan tidak merasa berat saat melakukan latihan. LAP bahkan menyayangkan latihannya saat libur lebaran. Menurut LAP libur latihan selama satu minggu sama dengan menghilangkan latihan selama satu tahun.

MKP sudah terbiasa melakukan latihan rutin balap sepeda setiap pagi dan sore. Namun MKP merasa dia melakukan latihan balap sepeda untuk mengisi waktu di UPTD Kampung Anak Negeri. Ketika sudah tidak menjadi anak binaan, MKP lebih berharap dapat bekerja dari pada meneruskan menjadi atlet.

IZ mencari tempat magang sendiri setelah lulus dari Surabaya Hotel School. Setelah diterima magang di Hotel bintang empat di Surabaya, IZ lebih banyak menghabiskan waktunya di tempat magang. Sebelum mengikuti pendidikan di Surabaya Hotel School, IZ mengaku mengikuti banyak kegiatan dan pelatihan di UPTD Kampung Anak Negeri. Menurut IZ dia bisa beradaptasi dengan baik, sehingga apapun kegiatan yang diikuti tidak terasa sebagai beban.

"Aku orangnya semangat mbak, semangat belajar. Suka capek (sibuk), jadi awalnya kerja dulu itu kerasa berat, sekarang udah nggak kerasa berat, udah biasa" (IZ)

AS mengambil program studi kapal pesiar saat mengikuti pendidikan di Surabaya Hotel School. Setelah lulus, AS berharap dapat bekerja di kapal pesiar. Namun untuk mencapai cita-citanya, AS harus mencari banyak pengalaman terlebih dahulu. AS bekerja di penginapan selama 8 jam, lalu dilanjutkan bekerja di centra kuliner. AS dan IZ merasa pekerjaan yang mereka lakukan merupakan pembelajaran bagi mereka. AS dan IZ belum mengutamakan upah kerja, namun lebih mengutamakan pengalaman yang mereka terima.
JTP juga pernah mengikuti pendidikan di Surabaya Hotel School, namun dia merasa tidak cocok dan memutuskan berhenti. JTP lebih berfokus belajar editing video dan membuat video singkat yang di unggah ke Instagram. Kedepannya JTP ingin mengunggah video secara rutin ke akun youtubenya. JTP mengaku dia tidak bisa fokus melakukan beberapa hal sekaligus. Sehingga saat JTP sedang berfokus menyelesaikan videonya, JTP tidak melanjutkan menulis buku atau melukis.

"aku lek lagi ngerjain iki, gak isok mbak lek ambek ngerjakno sing liyo. Kudu siji-siji" (JTP)

BS sengaja mengikuti berbagai kegiatan ekstrakurikuler di sekolahnya. Ekstrakurikuler yang diikuti meliputi PMR, pramuka, Konseling, dan Jujitsu, selain itu BS juga diterima sebagai anggota pasukan pengibar bendera di sekolah. BS mengaku sangat pemalu dan tidak bisa mengutarakan pendapat di depan banyak orang. Harapan BS dengan mengikuti berbagai kegiatan di sekolah, dia dapat mengatasi kekurangan pada dirinya. BS juga berharap menemukan 'keluarga' baru dari kegiatan yang dia ikuti.

AA mengikuti berbagai kegiatan di UPTD Kampung Anak Negeri. Kegiatan yang diikuti AA diantaranya Pelatihan wirausaha (kunir asem, cuci motor, dan cafe), band, dan melukis. AA juga pernah mengikuti pelatihan handicraft. AA merasa cukup piawai dalam membuat handicraft. AA bahkan pernah di rekrut pelatih handicraft untuk membuat handicraft di tempatnya. Sejak pelatih handicraft pindah, AA berhenti membuat handicraft karena tidak bisa menyediakan bahan yang diperlukan. Sebagian besar subjek sudah mengetahui serta dapat bertanggung terhadap tugas yang harus mereka lakukan.

Kepuasan subjek penelitian terhadap dirinya atau seberapa jauh subjek dapat 
menerima dirinya dapat dilihat dari diri penilaian. Diri penilaian yang baik juga dapat dilihat dari diri identitas dan diri perilaku (Sutataminingsih, 2008). Kepuasan diri yang rendah akan menimbulkan harga diri yang rendah dan dapat menimbulkan ketidakpercayaan pada diri (Fitts, 1971)

AA merasa puas dengan dirinya saat ini. AA merasa sudah bisa menolak ajakan atau hal yang tidak baik untuk dia. Sebelumnya AA merasa selalu menerima ajakan orang lain karena dia merasa tidak enak hati jika harus menolak. AA juga merasa di UPTD Kampung Anak Negeri dia memiliki kesempatan untuk berkembang melalui pelatihan yang ada.

"Puas mbak dari pada mbiyen. Nak kene enak, golek duwit sek gak soro, lek mbiyen kan angel nak njobo, nak dalan" (AA)

IZ, HPP, AS, JTP dan LAP merasa dirinya saat ini lebih baik jika dibandingkan dengan dirinya yang dulu sebelum berada di UPTD Kampung Anak Negeri. Namun di sisi lain mereka juga merasa belum puas karena belum mencapai target yang mereka harapkan. IZ masih ingin belajar dan kuliah di bidang perhotelan. HPP masih merasa kemampuannya kurang dalam bermain gitar solo. AS merasa belum puas karena belum mencapai cita-citanya untuk bekerja di perhotelan kapal layar. LAP juga memiliki target yang ingin dicapai dalam bidang balap sepeda yaitu meraih medali emas dalam ajang Pekan Olahraga Nasional (PON).

"Belum puas, cita-citaku dowo mbak sekan, pengen beli rumah, kan buat beli rumah prosesnya juga masih panjang" (AS)

BS merasa belum puas dengan dirinya. BS masih merasa malu dan tidak berani berbicara di depan umum. BS merasa terganggu dengan rasa malunya tersebut. BS mengaku sering sekali dia memiliki banyak hal yang ingin dia utarakan dalam pikirannya namun saat tiba gilirannya untuk berbicara, grogi yang dia rasa membuat dia lupa apa yang akan dikatakan.

"Durung puas mbak, aku sek isinan lek ngomong nak ngarepe wong akeh” (BD)

MKP mengaku pernah merasa stress memikirkan dirinya. MKP merasa banyak hal yang sebetulnya dapat ia capai. Namun, karena saat kecil MKP nakal dan tidak mau belajar, MKP merasa pesimis pada dirinya. MKP ingin berkuliah agar nantinya mendapat pekerjaan yang baik, namun MKP merasa dia tidak memiliki kemampuan akademis yang cukup.

"Lapo'o mbiyen kok koyok ngono (nakal), dadine saiki pengen lapo-lapo wes gaisok. Pengen kuliah tapi pikirane gak nutut." (MKP)

6 dari 8 subjek merasa puas dengan dirinya saat ini jika dibandingkan dengan sebelum mendapat binaan di UPTD Kampung Anak Negeri. 2 subjek lainnya belum merasa puas dengan dirinya saat ini. Meskipun sebagian besar subjek sudah merasa puas, namun subjek masih memiliki target yang ingin dicapai.

\section{PEMBAHASAN}

Subjek penelitian berada pada usia remaja yang merupakan tahap transisi antara kanak-kanak dan dewasa. Batasan usia rema menurut Peraturan Menteri Kesehatan RI Nomor 25 tahun 2014, batas usia remaja adalah antara 10 tahun sampai 18 tahun, sedangkan menurut WHO (dalam Kementerian Kesehatan RI) adalah 10 tahun sampai 19 tahun. Semua subjek penelitian telah memiliki prestasi sebagai hasil atas usaha yang telah dilakukan selama mengikuti binaan di UPTD Kampung Anak Negeri.

Prestasi yang diraih oleh subjek penelitian adalah prestasi dalam bidang olahraga bela diri (tinju, tapak suci, dan wushu), olahraga balap sepeda, dan seni (seni lukis dan penerbitan buku). 7 dari 8 
subjek penelitian memiliki prestasi di bidang olahraga, namun hanya tiga subjek yang masih menekuni bidang olahraga yang sama sampai saat pengambilan data.

Latar belakang pengasuhan anak asuh berdasarkan data yang dikumpulkan terdiri dari anak jalanan dan anak terlantar. Empat subjek penelitian memiliki latar belakang pengasuhan sebagai anak jalanan dan empat lainnya memiliki latar belakang pengasuhan sebagai anak terlantar. Temuan dalam data dokumentasi latar belakang anak asuh milik UPTD Kampung Anak Negeri menunjukkan, LAP adalah subjek penelitian yang tercatat memiliki latar belakang pengasuhan sebagai anak terlantar. Namun, saat wawancara subjek mengaku sebagai anak nakal. LAP diduga sebagai anak terlantar karena sering duduk-duduk di tempat yang sama pada malam hari, sehingga warga yang melapor mengira LAP adalah anak terlantar.

Semua subjek penelitian mengetahui latar belakang pengasuhannya dan anak asuh lainnya. Semua subjek penelitian sudah tinggal di UPTD Kampung Anak Negeri minimal selama dua tahun. Sebagian besar subjek penelitian sudah tidak merasa bahwa mereka adalah anak jalanan, anak nakal atau anak terlantar.

Identifikasi dimensi internal konsep diri anak asuh dari faktor diri identitas dapat diketahui bahwa sebagian besar anak asuh sudah mengetahui diri identitasnya. 5 dari 8 subjek penelitian sudah mengetahui perannya, meskipun tiga subjek lainnya masih bingung dengan identitas dirinya.

MKP, AA, dan JTP merupakan sebagian kecil subjek yang belum yakin dengan identitasnya. AA mengikuti banyak kegiatan di UPTD Kampung Anak Negeri. AA bukan tipe anak yang menutup diri, sebaliknya AA menyukai mencoba berbagai macam kegiatan untuk mengembangkan keterampilannya. Namun AA belum yakin sebagai apa identitas dirinya. JTP pernah menulis novel dan menghasilkan karya seni lukis yang laku terjual, namun kini JTP sedang menekuni bidang lain yaitu editing video. JTP suka mencoba dan mempelajari hal baru yang berkaitan dengan teknologi atau komputer.

MKP berlatih balap sepeda secara rutin setiap pagi dan sore hari. MKP merasa dia mengikuti latihan hanya untuk mengisi waktu luang selama di UPTD Kampung Anak Negeri. MKP tidak yakin bahwa balap sepeda merupakan suatu profesi yang tepat untuk dirinya.

HPP adalah salah satu subjek yang sudah meyakini identitas dirinya. HPP merasa dia adalah pemusik. Sejak memilih menekuni musik, HPP dapat mengembangkan potensinya yang semula hanya bisa bermain gitar menjadi bisa bermain bass, drum, dan keyboard. Pada usia remaja, anak cenderung menyukai mencoba berbagai hal baru. Masa remaja merupakan masa mencari identitas diri untuk menjelaskan siapa dirinya dan perannya dalam masyarakat.

Faktor kedua dalam dimensi internal konsep diri adalah diri perilaku. Diri perilaku ini berkaitan dengan diri identitas. Konsep diri yang baik menunjukkan adanya keserasian antara diri identitas dengan diri perilaku. Sebagian besar subjek penelitian sudah menyadari tugas dan dapat bertanggung jawab pada kegiatan rutin yang mereka lakukan.

LAP yang merasa identitasnya sebagai atlet balap sepeda, secara rutin memulai latihan balap sepeda pagi setelah sholat subuh dan sore hari. LAP merasa pada awal latihan terasa berat, namun karena sudah rutin dilakukan kini atas kesadarannya sendiri LAP merasa bahwa dia tidak boleh melewatkan latihan rutinnya. LAP bahkan rela untuk mempersingkat libur lebarannya agar dapat cepat kembali ke UPTD Kampung Anak Negeri dan dapat melakukan latihan rutin.

HPP yang merasa identitasnya sebagai pemusik juga hampir setiap hari melakukan latihan musik secara rutin baik dengan guru musik maupun belajar sendiri. HPP berlatih untuk dapat mencapai targetnya mengikuti lomba solo gitar. Setelah berada 
di UPTD Kampung Anak Negeri subjek memiliki keahlian yang tidak mereka miliki sebelumnya. Subjek diarahkan untuk ikut berbagai macam kegiatan, namun pada akhirnya subjek dapat memilih aktivitas yang mereka kehendaki.

Keserasian antara diri identitas dengan diri perilaku menunjukkan bahwa individu dapat mengenali dan menerima dirinya baik sebagai identitas maupun pelaku. Kaitan antara keduanya kemudian dapat dilihat pada diri sebagai penilai atau diri penilaian. Diri penilaian menentukan kepuasan subjek terhadap dirinya atau seberapa jauh subjek dapat menerima dirinya. Sebagian besar subjek penelitian dapat menerima dirinya yang sekarang. AA bahkan merasa sangat puas dengan dirinya saat ini, AA merasa dirinya yang sekarang jauh lebih baik dari pada saat masih menjadi anak jalanan. AA merasa di UPTD Kampung Anak Negeri dia memiliki kesempatan untuk berkembang melalui pembinaan yang diikuti.

Berbeda dengan AA, meskipun memiliki beberapa prestasi di bidang balap sepeda MKP merasa belum puas dengan dirinya. MKP justru merasa ada hal yang membuat dirinya menyesal dan belum bisa menerima dirinya. MKP menyesal karena dia dulu nakal dan tidak mau memanfaatkan waktunya saat masih sekolah, akibatnya meskipun belum mencoba dan berusaha MKP sudah putus asa dan merasa tidak akan bisa kuliah karena keterbatasan kemampuan yang dimiliki.

Ketidakpuasan terhadap diri dapat menjadi pendorong atau motivasi untuk terus berkembang. Namun dapat juga membuat seseorang mudah putus asa. Hal ini sesuai dengan teori konsep diri yang dikemukakan oleh Fitts, (1971) bahwa kepuasan diri yang rendah akan menimbulkan harga diri yang rendah dan akan mengembangkan ketidakpercayaan pada diri individu. Dalam mencapai aktualisasi diri, kepercayaan diri diperlukan untuk menunjang terbentuknya aktualisasi diri dalam individu (Patioran, 2013).

Konsep diri yang positif diibaratkan berisi berbagai kepribadian individu, dimana individu dapat menyimpan informasi tentang dirinya sendiri, baik itu informasi negatif atau positif. Individu dengan konsep diri positif dapat memahami dan menerima bermacammacam fakta tentang dirinya. Individu dapat menerima dirinya sendiri secara apa adanya. (Sutataminingsih, 2009)

Pengharapan dari setiap subjek mengenai dirinya masing-masing menentukan, bagaimana subjek bertingkah laku dalam kehidupannya. Bila individu berpikir bahwa dirinya mampu melakukan banyak hal, maka individu cenderung akan meraih sukses. Sebaliknya, jika individu berpikir bahwa dirinya gagal dalam berbagai hal, maka sebenarnya individu tersebut menyiapkan diri mereka untuk gagal. Penelitian Dwija (2008) menunjukkan adanya hubungan yang signifikan antara konsep diri, motivasi berprestasi dan perhatian orang tua.

Penjabaran mengenai ketiga bagian dari dimensi internal pada anak asuh, menunjukkan bahwa masing-masing bagian memiliki fungsi yang berbeda namun saling melengkapi, berinteraksi, dan membentuk diri dan konsep diri secara utuh dan menyeluruh (Sutataminingsih, 2009).

WHO (dalam The UK's Faculty Of Public Health) mengartikan kesehatan mental adalah keadaan baik di mana individu menyadari kemampuannya sendiri, dapat mengatasi tekanan atau kegelisahan secara wajar, dapat bekerja secara produktif, bermanfaat dan dapat memberikan kontribusi pada komunitasnya. The UK's Faculty of Public Health mengatakan kemampuan mengatasi stres normal dalam hidup merupakan komponen penting dari berbagai definisi kesehatan mental. Beberapa penelitian dan sudut pandang para ekonom, 
bekerja secara produktif dianggap sebagai komponen utama dalam kesehatan mental.

\section{SIMPULAN}

Kesimpulan dalam penelitian ini semua subjek penelitian berjenis kelamin lakilaki dengan rentang usia 15 tahun sampai 19 tahun. Semua subjek penelitian masih tergolong usia remaja yang sedang dalam masa pencarian jati diri untuk mengetahui identitas dan peran dirinya dalam masyarakat. Latar belakang pengasuhan subjek penelitian adalah anak jalanan dan anak terlantar. Latar belakang pengasuhan tidak menghalangi anak asuh untuk meraih prestasi dalam bidang seni lukis, seni tulis, olahraga bela diri, dan olahraga balap sepeda.

Dimensi internal konsep diri meliputi diri identitas, diri perilaku, dan diri penilaian. Faktor dalam dimensi internal anak asuh lebih banyak ditunjukkan dalam diri pelaku dan diri penilaian. Sebagian besar subjek puas dengan dirinya saat ini jika dibandingkan dengan sebelum berada di UPTD Kampung Anak Negeri. Subjek merasa telah memiliki kemampuan yang dapat diterapkan dan memiliki gambaran target ke depan untuk dicapai. Subjek yang memiliki kepuasan dan dapat menerima dirinya akan meningkatkan harga diri.

Saran bagi pihak UPTD Kampung Anak Negeri diharapkan dapat memberikan konseling dengan lebih aktif pada setiap anak asuh sehingga dapat memberi pengarahan secara langsung pada setiap anak asuh untuk membangun konsep diri mereka. Pembina UPTD Kampung Anak Negeri dapat mengadakan kelas motivasi yang menceritakan atau mendatangkan sosok inspiratif yang dapat memotivasi anak asuh untuk menemukan identitas atau peran yang tepat untuk dirinya. Memberikan apresiasi kepada anak asuh yang berprestasi maupun yang melaksanakan tugasnya di UPTD Kampung Anak Negeri dengan baik, sehingga anak asuh merasa di hargai dengan apresiasi tersebut serta dapat membesarkan hatinya dan meningkatkan motivasi anak asuh. Orang tua wali anak asuh menyediakan waktu quality time untuk berkomunikasi terbuka dengan anak asuhnya dan membantu anak asuh mengatasi masalah pribadi yang dihadapi.

\section{DAFTAR PUSTAKA}

Agustian, M., Prasadja, H. 2000. Anak Jalanan dan Kekerasan Pusat Kajian Pembangunan Masyarakat. Unika Atma Jaya. Jakarta: Departemen Sosial RI.

Dhar, Neera dkk. 2013. Spiritual Health, the fourth dimension: a public health perspective. WHO South-East Asia Journal of Public Health. Tersedia di http://www.searo.who.int/publications/ journals/seajph/seajphv2n1_p3.pdf?ua=1 [29 Juli 2017]

Dwija, I Wayan. 2008. Hubungan Antara Konsep Diri, Motivasi Berprestasi dan Perhatian Orang Tua Dengan Hasil Belajar Sosiologi Pada Siswa Kelas II SMA Unggulan di Kota Amplapura. Jurnal Pendidikan dan Pengajaran Universitas Pendidikan Ganesha. Jurnal Pendidikan dan Pengajaran. Tersedia di http:// ejournal.undiksha.ac.id/index.php/JPP/ article/view/1977 [6 juli 2017]

Fitts, William H. 1971. The Self Concept and Psychology. California: Western Psychological Service.

Freud, Sigmund. 2002. General Introduction to Psychoanalysis: Psikoanalisis Sigmund Freud. Diterjemahkan oleh Ira Puspitorini. Yogyakarta: Ikon Teralitera

Patioran, Desi Natalia. 2013. Hubungan Antara Kepercayaan Diri dan Aktualisasi Diri Pada Karyawan PT. Duta Media Kaltim Press. [e-journal] Volume 1(1): 10. Tersedia di http://ejurnal.untag-smd.ac.id/ index.php/MTV/article/view/217/326 [diakses pada 20 Juli 2017]

Rahayu, Ade R. 2016. Pola Interaksi Sosial Anak Asuh Dalam Konteks Kesehatan Sosial. E-Journal Penelitian Kesehatan, Volume 14 (4):253. Tersedia di: http:// journal.poltekkesdepkes-sby.ac.id/index. 
php/JPK/article/view/167/165 [diakses tanggal 14 Agustus 2017]

Redjeki, Sri. 2013. Membangun Konsep Diri Positif Pada Anak. Majalah Ilmiah Pawiyatan. Volume 20 (4): 37. Tersedia di http://download.portalgaruda.org/article. php article $=251794 \& \mathrm{val}=6766 \&$ title $=$ Membangun\%20Konsep\%20Diri\%20 Positif\%20Pada\%20Anak [diakses pada 20 Juli 2017]

Santoso, Meilanny Budiarto. 2016. Kesehatan mental dalam perspektif pekerja sosial. Social Work Jurnal [e-Journal], volume(6): 153. Tersedia di http://fisip.unpad.ac.id/ jurnal/index.php/share/article/view/75 [diakses tanggal 20 Juli 2017]

Sari, Kumala. 2014. Hubungan Antara Konsep Diri Dan Kepercayaan Diri Pada Sales Promotion PT Nutrifood Indonesia. [ejurnal]. Volume 2(1). Diakses di http:// ejurnal.untag-smd.ac.id/index.php/MTV/ article/view/593/1134 [diakses pada 14 Agustus 2017]

Shafira, Greisca Rosa. 2017. Konsep Diri Anak Asuh Kaitannya dengan Aktualisasi Diri Dalam Konteks Kesehatan Mental. Skripsi. Surabaya: Universitas Airlangga.

Sutataminingsih, Raras. 2009. Konsep Diri. Sumatera Utara: Fakultas Psikologi Universitas Sumatera Utara. Tersedia di http://repository.usu.ac.id/bitstream/123456 789/3622/1/09E01769.pdf [15 Juni 2017] The UK's Faculty of Public Health. 2010. Concepts of Mental and Social Wellbeing. London. Tersedia di http://www.fph.org. uk/concepts_of_mental_and_social_ wellbeing\#2top [10 Juli 2017] 